\title{
A conflict between a threatened deer and indigenous agriculture: Tarukas (Hippocamelus antisensis D'Orbigny) and Aymara farmers in northern Chile
}

\author{
El conflicto entre un ciervo amenazado y agricultura indígena: Tarukas (Hippocamelus \\ antisensis D'Orbigny) y agricultores Aymaras en el norte de Chile
}

\section{Alejandra E. Muñoz ${ }^{1}$, Robert Petitpas ${ }^{1}$, Juan C. Marín² \& Cristián Bonacic ${ }^{1, *}$}

${ }^{1}$ Fauna Australis Wildlife Laboratory, Department of Ecosystems and Environment, Pontificia Universidad Católica de Chile, Casilla 306-22, Vicuña Mackenna 4860, Macul, Santiago, Chile.

${ }^{2}$ Genomic and Biodiversity Laboratory, Department of Basic Sciences, Universidad del Bío-Bío, Av. Andrés Bello s/n, Casilla 447, Chillán, Chile.

*E-mail:bona@uc.cl

\section{ABSTRACT}

The taruka is one of the least known deer species of the world. Its range includes the northern Andean mountains in Chile, where their relationship with Aymara peasants is conflictive because of crop raiding. The aim of this study is to understand the nature of this conflict in Chile, and identify socio-ecological features that may explain it. Data of different sampling dates from 2003 to 2011 of night transects on roads, crop examination, interviews and direct sighting of tarukas were used to understand its ecology and relationship with local peasants. Peasants interviewed $(n=47)$ cultivated mainly corn $(85.1 \%)$ and alfalfa $(74.5 \%)$ in small farms and $83 \%$ of them raise livestock. The conflict is widespread in Parinacota Province, where tarukas effectively consume crops, mainly abandoned alfalfa at night. The occurrence of crop raiding is not positively correlated with dry season as expected. However crop consumption is low (10.3\% average of damaged plants in crop plots). In Del Tamarugal Province only $29.4 \%$ of peasants manifested conflict with tarukas but they did report conflict with other ungulates. Day sightings showed 78 tarukas in 34 encounters during 59 days. Night surveys yielded $11.6 \pm 7.4$ tarukas/ survey, sighted only in alfalfa plots. Aymara agriculture feeds tarukas and is declining because of rural-urban migration. The conflict must be considered in the conservation strategy of the species.

Keywords: crop raiding, human-wildlife conflict, indigenous agriculture, native deer.

\section{RESUMEN}

La taruka es una de las especies de ciervo menos conocida del mundo. Su rango de distribución incluye el extremo norte de los Andes en Chile, donde tienen conflicto con agricultores Aymaras por daño a cultivos. El objetivo del estudio es entender la naturaleza del conflicto en Chile, e identificar características socio-ecológicas que pueden explicarlo. Se usaron datos entre el 2003 y 2011 de transectos nocturnos, inspección de cultivos, entrevistas y avistamientos directos para entender su ecología y relación con los agricultores locales. Los agricultores entrevistados $(n=47)$ cultivan principalmente maíz $(85,1 \%)$ y alfalfa $(74,5 \%)$ y $83 \%$ de ellos cría ganado. El conflicto es difundido en la Provincia de Parinacota donde tarukas efectivamente consumen principalmente alfalfa en potreros abandonados de noche. La ocurrencia de consumo de cultivos allí no está positivamente correlacionada con la estación seca como era esperado. Sin embargo, el consumo de cultivos es bajo (10,3\% promedio de plantas dañadas en parcelas). En la Provincia 
del Tamarugal solo un $29,4 \%$ de los agricultores manifestaron tener conflictos con tarukas pero mantienen conflictos con otros ungulados. En el día se avistaron 78 tarukas en 34 avistamientos durante 59 días. Los transectos nocturnos arrojaron 11,6 \pm 7,4 tarukas/transecto, avistadas sólo en alfalfa. La agricultura Aymara alimenta tarukas y está declinando por migración rural-urbana. El conflicto debe ser considerado en la estrategia de conservación de la especie.

Palabras clave: agricultura indígena, ciervo nativo, conflicto ser humano-vida silvestre, consumo de cultivos.

\section{INTRODUCTION}

Many large wild herbivores worldwide have conflicts with humans and conservation problems, and are excluded from areas where humans live and farm (Woodroffe et al. 2005; Gordon 2009; Shaffer et al. 2019). This is true for Andean mountains where ancestral agriculture and livestock production are combined with wild large herbivores presence, generating conflicts because of livestock competition and crop raiding (Borgnia et al. 2008; Bonacic \& Ibarra 2010).

Taruka Hippocamelus antisensis D'Orbigny 1834, has been considered one of the least known deer species worldwide (Weber \& Gonzalez 2003). The species is a medium size deer that inhabits the Andes from northern Peru to northern Chile and Argentina, including Bolivia (Barrio 2010). The taruka is globally threatened and it is categorized as vulnerable in the IUCN Red List (Barrio et al. 2017). In Chile, tarukas live in a relatively small area in the north of the country, with an estimated population of no more than 1,000 individuals and considered in danger of extinction (MINSEGPRES 2007; Sielfeld \& Guzmán 2011).

In Chile, taruka's habitat is mainly concentrated between 2,500 to $4,000 \mathrm{~m}$ above sea level (masl), in a landscape dominated by rocky slopes covered by a shrub steppe (Mata et al. 2019). This ecosystem harbors a declining population of Aymara (second most populous ethnic group in Chile) who lives mainly as subsistence peasants (Caqueo-Urízar et al. 2014).

The evidence of coexistence with Aymara farmers suggests a negative relationship because of crop raiding in last decades (Sielfeld et al. 1999). Tarukas may be affected by a reduction of habitat availability and quality due to conversion of natural habitat for agriculture and competition with livestock (Sielfeld et al. 1999). On the other hand, remnant Aymara peasants report that tarukas, and also guanacos Lama guanicoe Müller, feed on and damage crops
(Sielfeld et al. 1999; Jiménez 1994). It has been proposed that tarukas provide an increased grazing pressure on crops during dry season, when wild vegetation cover and herbaceous plant availability are at minimum (Carrasco et al. 1992). In addition, forage resources (wild plants and crops) are shared with livestock. Aymaras used domestic camelids as traditional livestock, but in the last decades, these were partially replaced by goats and sheep (INE 1997; INE 2007).

However, co-existence between Aymara peasants and tarukas is not a recent phenomenon. The first record of humans using tarukas is from around 9,500 - 7,500 years B.P. (Wheeler et al. 1976). The Amerindian chronicler from Southern Peru, Guaman Poma illustrated crop protection against cervids in the seventeen century and therefore it is likely that the conflict has been for centuries. His work entitled "February: Time of watching the maize at night", depicts an Inca woman driving off a deer (being taruka one of the possible species) from the maize (Det Kongelige Bibliotek 2001). Particularly, Aymaras have been present in the study area at least for 2,000 years (Carevic 2008), and living from agriculture since then.

In order to find sustainable solutions to wildlife-human conflicts, social, geographical and ecological components must be considered (Shaffer et al. 2019). Taruka is one of three native deer from Chile, but the least studied; and although recent works of the species has been documented (e.g., Fuentes-Allende et al. 2016; Mata et al. 2019), information characterizing their conflict with agriculture is scarce. In this context, the aim of this research is to identify and characterize the conflict between tarukas and local Aymara agriculture (crops cultivation and livestock raising) in northern Chile. In particular, we evaluated behavioral features of tarukas which generates the conflict (crop selection, level of consumption and potential seasonality of grazing patterns), and we examine the perceptions of local people about the species. 


\section{MATERIALS AND METHODS}

\section{STUDY AREA}

The study area is located in the pre-Andean mountains of northern Chile ( $18^{\circ} 12^{\prime} \mathrm{S}-69^{\circ} 33^{\prime} \mathrm{W}$ to $\left.20^{\circ} 01^{\prime} \mathrm{S}-69^{\circ} 12^{\prime} \mathrm{W}\right)$, in Arica and Parinacota and Tarapacá regions, where tarukas inhabit. This is a narrow strip (less than $50 \mathrm{~km}$ wide) between the desert at lower altitude to the west and the wetter and higher Altiplano to the east. The area presents a tropical xeric bioclimate with an annual average temperature of $9.2{ }^{\circ} \mathrm{C}$ (Luebert \& Pliscoff 2006). Annual rainfall ranges from 50 to $200 \mathrm{~mm}$ and is highly concentrated during summer (above $90 \%$ between December and March; Muñoz \& Bonacic 2006). Vegetation is represented by semi-arid shrubland and scarce grasses; herbaceous plants emerge after summer rainfall (around March to May; Muñoz \& Bonacic 2006), increasing the availability of native feeding resources for tarukas.

The Aymara agriculture in the area is based on a mixture of indigenous and exotic crops, as well as subsistence ruminant livestock. Crops are mainly produced in terraces. Human population in the area has a low density ( 0.25 inhabitants/ $\mathrm{km}^{2}$ ) (Comuna de Putre 2012). The major villages in the study area is Belén, which has about 148 translocal inhabitants (i.e. constantly migrating between the city and farming villages) and six school students; the rest of prospected villages have less than 20 permanent inhabitants (village dwellers' personal communication, January 2011; Comuna de Putre 2012).

\section{Data COllection}

Data of different sampling periods from January 2003 to January 2011 was collected using several methods, which allowed approaching the different aspects (social, ecological and spatial) considered in this study (Table 1). Sampling was focused around villages because agricultural activity is concentrated there, thus these are the places of potential conflicts with tarukas.

\section{DAY SIGHTINGS}

Daytime records were obtained around Murmuntani, Chapiquiña and Belén villages between 2003 and 2006 in 59 fieldwork days (Table 1; Fig. 1). Two incidental sightings in Putre town were also considered as valid records. During the day, random walks were taken in different transects on hills around these villages and every time a taruka was sighted, it was recorded (GPS position, time, type of habitat, number of animals). Vegetation type was classified as crop, shrubland and no vegetation (e.g. roads). In each sighting the number of individuals, age class (fawn or adult) and sex (determined by the existence of antlers in adult males) also were recorded. This category includes all records that could be done with natural light (ca 6:30 to 21:00 in summer).

\section{QuestionNAIRE}

A questionnaire was applied to determine their perceptions about the tarukas and its impact on crops to local peasants in Parinacota and Tamarugal Province during 2010-2011 (Table 1). Questions about farming practices (cultivated species, crop size, herding systems, and species and number of individuals) and damage caused by wild animals were included (occurrence of crop, number of individuals sighted, time of sightings and protection methods used; see Appendix 1).

TABLE 1. Sampling periods according to working days and type of data collected. / Períodos de muestreo según días de terreno y tipo de datos colectados.

\begin{tabular}{lccccc}
\hline Period & Working days & Day Sightings & Night records & $\begin{array}{c}\text { Farmer } \\
\text { questionnaire }\end{array}$ & $\begin{array}{c}\text { Crop } \\
\text { assessment }\end{array}$ \\
\hline January 2003 & 22 & $\mathrm{x}$ & $\mathrm{x}$ & $\mathrm{x}$ & $\mathrm{x}$ \\
April-May 2003 & 16 & $\mathrm{x}$ & $\mathrm{x}$ & $\mathrm{x}$ & \\
November 2003 & 13 & $\mathrm{x}$ & $\mathrm{x}$ & $\mathrm{x}$ & \\
April-May 2004 & 4 & $\mathrm{x}$ & $\mathrm{x}$ & & \\
March 2005 & 5 & $\mathrm{x}$ & $\mathrm{x}$ & & \\
August 2006 & 4 & & $\mathrm{x}$ & & \\
December 2008 & 3 & & & & \\
October 2010 & 4 & & $\mathrm{x}$ & $\mathrm{x}$ & \\
January 2011 & 6 & & & & \\
\hline
\end{tabular}




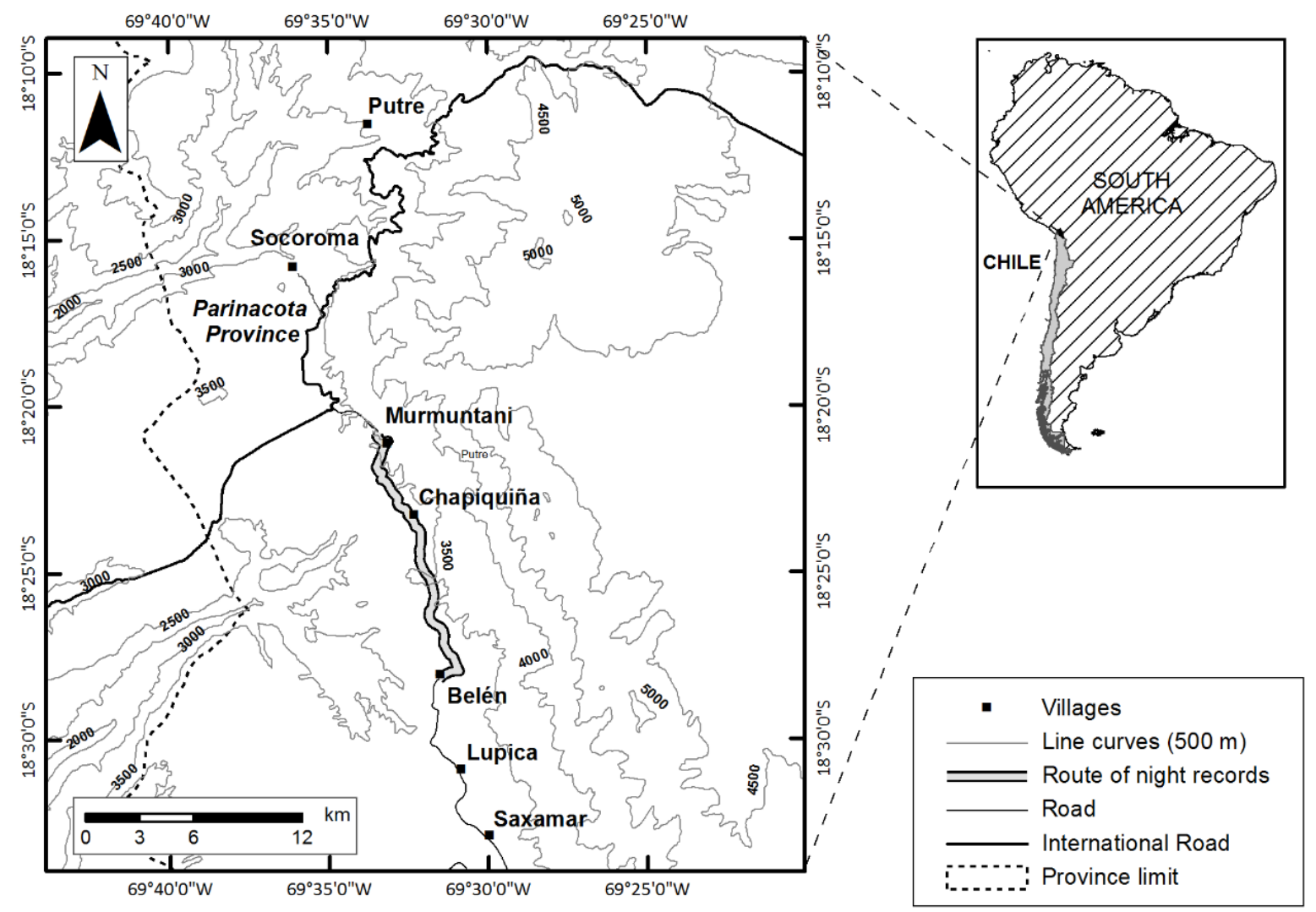

Figure 1. Main villages and route of night surveys of tarukas in the study area in Arica y Parinacota region. / Principales pueblos y caminos de muestreo nocturno de tarukas en el área de estudio en la Región de Arica y Parinacota.

A total of forty seven peasants (30 males and 17 females) were interviewed: 27 from five towns of Parinacota Province (Murmuntani, Chapiquiña, Belén, Lupica and Saxamar) and 20 peasants from nine villages of Tamarugal Province (Nama, Chiapa, Jaiña, Achacagua, Sibaya, Coscaya, Poroma, Yamiña and Noasa). All respondents were older than 30 years old (most above 50 years old) and 36\% were female and $64 \%$ male. In others five villages (Parca, Camiña, Limaxiña, Huaviña and Guatacondo) peasants were interviewed but those questionnaires were discarded because those villages are in lower altitudes (under 2,800 masl) and their inhabitants did not report wild native ungulate presence neither conflict.

\section{CROP ASSESSMENT}

Twenty plots located near from the road between Chapiquiña and Belen were examined to evaluate foraging damage on crops in January 2003 (aside from those surveyed by night; Fig. 1). All crops were in vegetative phenological stage, except oregano crop which was flowering. Signs of ungulates presence (footprints, feces, hair, antlers) and methods of crop protection were recorded. Individual plants were examined in order to evaluate incidence of trampled plants and grazing existence by visual inspection of foliage removed. Then the percentage of damaged plants per plot was obtained.

\section{NIGHT RECORDS IN CROPS}

Night surveys were carried out to evaluate potential seasonal patterns of grazing pressure on crops between 2003 and 2006 and in 2008 in Parinacota Province and 2011 in Del Tamarugal Province. A total of 18 crops were surveyed in $28 \mathrm{~km}$ of a secondary road of Parinacota Province (Fig. 1). Plots were chosen randomly from sites less than $100 \mathrm{~m}$ from the road or directly adjacent to the road. The plots were homogeneous in size (ca $80 \%<1$ ha). Two extra plots without crops were used as control (Plots 1 and 20 located at c.a. $500 \mathrm{~m}$ in both route ends). This road has almost no traffic during the day and none at night; it has a total length of $28 \mathrm{~km}$ between plot 1 and 20 .

Night surveys consisted in a road trip where plots (the 18 crop plots plus the two control plots) were illuminated using a beam to detect and count tarukas. Sampling was initiated at around 23:00 and lasted about two hours. A total of nine night surveys were carried out between 2003 and 2008. The 
minimum time between one night survey and the next were 19 days.

In order to protect crops, peripheral fences were erected in 2004 surrounding two villages (8.55 and $10.86 \mathrm{~km}$ long respectively), then in 2006, fences were placed around a third village (10.86 km long) (CONAF 2006a, 2006b).

Differences in total number of tarukas in crop plots and the number of crop plots with taruka presence were compared between samplings before and after summer rainfall using a T-test (after testing normality through Kolmogorov-Smirnov test). Samples carried out between March and May were considered "after summer rainfall" period. All remaining surveys were considered "before summer rainfall" period.

Only two surveys were conducted In Del Tamarugal Province during January 2011 (January 8 and 11). One of them between Chiapa and Jaiña villages where 8 crop plots were checked in $8 \mathrm{~km}$ of length. The other near from Coscaya Village where $8 \mathrm{crop}$ plots were surveyed in a road of $5 \mathrm{~km}$. But these surveys were not considered in the analysis since no taruka was observed; only a group of donkeys was registered in crops near Jaiña. Precise date and season of samplings considered in the analyses are shown in Table 2.

TABLE 2. Number of taruka per crop plot in night surveys and description of plots surveyed. / Número de tarukas por potrero cultivado en muestreos nocturnos y descripción de potreros prospectados.

\begin{tabular}{|c|c|c|c|c|c|c|c|c|c|c|c|}
\hline \multirow[b]{2}{*}{ Plot } & \multirow[b]{2}{*}{ Zone } & \multirow[b]{2}{*}{$\begin{array}{l}\text { Crop type } \\
\text { (Januray 2003) }\end{array}$} & \multicolumn{9}{|c|}{ Date (relative to summer rainfall) } \\
\hline & & & $\begin{array}{l}9.1 .03 \\
\text { (before) }\end{array}$ & $\begin{array}{l}28.1 .03 \\
\text { (before) }\end{array}$ & $\begin{array}{c}25.4 .03 \\
\text { (after) }\end{array}$ & $\begin{array}{c}10.5 .03 \\
\text { (after) }\end{array}$ & $\begin{array}{c}15.11 .03 \\
\text { (before) }\end{array}$ & $\begin{array}{c}27.4 .04 \\
\text { (after) }\end{array}$ & $\begin{array}{l}8.3 .05 \\
\text { (after) }\end{array}$ & $\begin{array}{l}22.8 .06 \\
\text { (before) }\end{array}$ & $\begin{array}{r}14.12 .08 \\
\text { (before) }\end{array}$ \\
\hline $1^{*}$ & Murmuntani & no crop & 0 & 0 & 0 & 0 & 0 & 0 & 0 & 0 & 0 \\
\hline 2 & Murmuntani & oregano, alfalfa & 6 & 0 & 5 & 0 & 0 & 4 & 0 & 0 & 0 \\
\hline 3 & Murmuntani & oregano, alfalfa & 0 & 6 & 2 & 1 & 6 & 0 & 1 & 0 & 0 \\
\hline 4 & Murmuntani & alfalfa & 0 & 0 & 0 & 0 & 3 & 0 & 0 & 0 & 0 \\
\hline 5 & Chapiquiña & broad bean & 0 & 0 & 0 & 0 & 0 & 0 & 0 & 0 & 0 \\
\hline 6 & Chapiquiña & alfalfa, potato, corn & 0 & 0 & 0 & 0 & 0 & 0 & 0 & 0 & 0 \\
\hline 7 & Chapiquiña & alfalfa & 0 & 0 & 0 & 0 & 0 & 0 & 0 & 0 & 1 \\
\hline 8 & Chapiquiña & corn, alfalfa & 0 & 0 & 0 & 0 & 0 & 0 & 0 & 0 & 0 \\
\hline 9 & Chapiquiña & potato & 0 & 0 & 0 & 0 & 0 & 0 & 0 & 0 & 0 \\
\hline 10 & Chapiquiña & alfalfa & 0 & 0 & 0 & 0 & 0 & 0 & 0 & 0 & 0 \\
\hline 11 & Chapiquiña & alfalfa, corn, potato & 0 & 0 & 0 & 0 & 0 & 0 & 0 & 8 & 0 \\
\hline 12 & Chapiquiña & alfalfa, corn, potato & 0 & 0 & 0 & 0 & 0 & 0 & 0 & 0 & 0 \\
\hline 13 & Chapiquiña & $\begin{array}{l}\text { alfalfa, broad bean, } \\
\text { corn, oregano }\end{array}$ & 5 & 0 & 0 & 0 & 0 & 0 & 0 & 0 & 0 \\
\hline 14 & Belén & alfalfa & 0 & 1 & 11 & 2 & 1 & 0 & 0 & 0 & 0 \\
\hline 15 & Belén & alfalfa & 0 & 0 & 0 & 0 & 0 & 0 & 0 & 0 & 0 \\
\hline 16 & Belén & alfalfa & 0 & 0 & 9 & 0 & 0 & 10 & 0 & 0 & 0 \\
\hline 17 & Belén & alfalfa & 0 & 5 & 0 & 2 & 0 & 0 & 0 & 8 & 7 \\
\hline 18 & Belén & corn, potato & 0 & 0 & 0 & 0 & 0 & 0 & 0 & 0 & 0 \\
\hline 19 & Belén & broad bean & 0 & 0 & 0 & 0 & 0 & 0 & 0 & 0 & 0 \\
\hline $20^{*}$ & Belén & no crop & 0 & 0 & 0 & 0 & 0 & 0 & 0 & 0 & 0 \\
\hline Total & & & 11 & 12 & 27 & 5 & 10 & 14 & 1 & 16 & 8 \\
\hline
\end{tabular}

*: control sites 


\section{RESULTS}

Our evidence shows that in Parinacota Province the conflict between tarukas and Aymara agriculture exists and is relevant for Aymara peasants: tarukas eat crops during different seasons and practically all peasants have a negative perception of their presence. However, except for abandoned alfalfa plots, the damage on crops is infrequent and, when exists is small.

Tarukas were not found in either day or night surveys in Del Tamarugal province of Tarapacá (in their southern limit of their distribution in the country), but were reported in interviews and records from professionals of SAG and CONAF. Peasants did not report a major conflict with tarukas, but mainly with guanacos and feral donkeys.

\section{DAY SIGHTINGS}

During daytime surveys, a total of 78 individuals were seen in 34 different sightings. Excluding the two incidental encounters in Putre, the rate of diurnal encounters with tarukas was 0.58 sighting/day. Tarukas were observed between 3,281 and 3,840 masl mainly in sun-exposed rocky slopes of high inclination ( $58.8 \%$ of sightings $\geq 40^{\circ}$ ) covered mainly by shrublands $(73.5 \%)$ and followed by crops $(20.6 \%$ alfalfa and $2.9 \%$ potato). Sightings occurred mainly in the second half of the day (64.7\% after 14:00).

Group size ranged from one to seven individuals with a median equal to two tarukas. Sightings included single male (23.5\% of sightings), single female (8.8\%), single undetermined individual (11.8\%), mixed group (26.5\%; adult males and females, which often include young individuals), male group (5.9\%), female group (2.9\%; one sighting), family group (i.e. with fawns, 5.9\%) and undetermined group (14.7\%). Average flight distance of tarukas from observer was $150.8 \pm 101.9 \mathrm{~m}$.

It was possible to observe tarukas eating crops in five diurnal sightings (alfalfa and potato plants) and in three occasions, we observed consumption of wild vegetation: Balbisia microphylla (Phil.) Reiche, Coreopsis suaveolens (Sherff), and a fruit of a native columnar cactus species (Oreocereus sp.).

\section{QUESTIONNAIRE}

\section{A) Farming characterization:}

Farms consist on small plots ranging from 0.003 ( 1 "era" = $30 \mathrm{~m}^{2}$ ) to 10 ha, but $76 \%$ of them had $\leq 2$ ha. All cultivated species were vegetable crops and alfalfa is the only forage species cultivated. The main crops were corn $(85.1 \%$ of the peasants), alfalfa $(74.5 \%)$, potato $(61.7 \%)$ and broad bean (48.9\%). Almost all peasants had livestock (83\%), mainly goats and sheep (64.1\% of livestock keepers for each species).
Herd size per livestock keeper ranged from 5 to 170 animals and $85 \%$ of them had $\leq 60$ animals.

\section{B) Perception of aymara peasants about tarukas:}

The perception of Aymara peasants interviewed toward wild ungulates was negative and $91.5 \%$ of peasants reported been affected by wild ungulates (tarukas, guanacos and feral donkeys). From North to South, $96 \%$ of peasants had conflicts with tarukas and guanacos in Parinacota Province and only $29.4 \%$ of peasants manifested conflict with tarukas in Del Tamarugal Province. More complains related to damage on crops caused by guanacos ( $64.7 \%$ of peasants in conflict) and feral donkeys (58.8\%) in Del Tamarugal Province.

In some cases peasants use methods to protect their crops from wildlife, mainly scarecrow $(51.2 \%$ of the 43 respondents in conflict) followed by dogs (37.2\% of peasants). Only $14.9 \%$ of peasants interviewed had fenced crops.

\section{Crop assessment}

Crop foraging was concentrated on abandoned alfalfa pastures and in affected non-abandoned crops the percentage of damage was below $20 \%$. Except for alfalfa, consumption of crops by wild animals is occasional and marginal (Appendix 2). The damage on crops, when exists, is caused by grazing and trampling.

In general, crops had deficient management by peasants. Plant populations in plots were generally low and irregularly distributed. The most widespread type of irrigation was flood irrigation, which does not work well on irregular terrain as in the study area.

\section{NIGHT RECORDS IN CROPS}

Night surveys yielded $11.6 \pm 7.4$ tarukas/survey and $0.4 \pm 0.3$ tarukas $/ \mathrm{km}$ of road (average \pm standard deviation hereafter; Table 1). Plots with tarukas contained from 1 to 11 individuals. There were $2.4 \pm 0.9$ plots with taruka presence per night survey. There was no significant difference in total number of tarukas per night survey before and after summer rainfall, neither for number of plots with taruka presence.

The presence of tarukas in night surveys exhibited an abrupt but transient decrease after the fence installation around villages and crops in 2005. Tarukas started to appear again in 2006 and 2008, which contributed to the high variability presented in the records throughout the study period (Table 2).

Tarukas were sighted only in alfalfa plots at night. In most of these encounters, tarukas were present in more than one occasion and in some plots on several occasions (Table 1). Night surveys did not show tarukas in Del Tamarugal Province between Chiapa and Jaiña. Between Poroma and Coscaya 
only four donkeys (Equus asinus Linnaeus) were recorded in an abandoned alfalfa plot but tarukas were not seen.

\section{DISCUSSION}

Our results indicate the existence of a conflict between Aymara peasants and tarukas that affect both human and tarukas. We identified the perceptions of local people in mostly the entire distribution of the species in Chile; this conflict was more intense in the northern distribution range in the country, where the species has been mainly registered (Mata et al. 2019). As the species abundance decreases until it disappears in the Southern tip, the conflict between peasants and wild ungulates persists but mainly with guanacos and recently with feral donkeys, but no conflict was perceived with tarukas.

Crop consumption by tarukas usually takes place at night, when peasants are not present, thus this species is considered more harmful than guanacos, which have only diurnal activity and peasants are able to repel them. The presence of feral donkeys as another threat for crops in Tarapacá is worrisome since feral donkeys, as we verified, also can forage crops during night. Nonetheless, apparently there is a low potential of competition of feral donkeys with tarukas and other native ungulates in the area (guanacos and vicuña) (Fuentes-Allende et al. 2016; Malo et al. 2016).

According to respondents all crops except oregano are eaten by tarukas. Methods used to avoid crop raiding were inefficient or nonexistent. Most plots had no fences, and scarecrows (the most common protection measure) are useless since wild ungulates were seen foraging in fields with scarecrows. Therefore, it is not surprising that Aymara peasants have a negative perception of tarukas. Nevertheless, Aymaras know that the species is protected and during fieldwork we did not find evidence of illegal hunting.

We recorded tarukas feeding on crops in our surveys and this was also confirmed by Aymara peasants. However, in the assessment of plants damaged it was not possible to determine how much of the consumption corresponded to taruka since guanacos are also present, and footprints of these animals are practically identical (Skewes 2009). Damage by domestic animals is unlikely to be important as peasants mentioned that their animals do not forage their crops.

Although we believe that the perception of Aymara peasants about the conflict might by overstated, it is also understandable that yield losses, however small, worsen their difficult economic condition. Exaggeration of conflicts has been reported as a common situation when there is a poor access to resources (Distefano 2005). The claim of conflict between agriculture and protected wildlife species has also been used by Aymara peasant to get financial assistance from the local authorities.

Notwithstanding, the persistence of Aymara traditional agriculture is affected by more factors than their relationship with tarukas and wildlife. Aymara people are migrating from the countryside to coastal cities. In the whole Putre County the population declined by more than $40 \%$ between 1982 and 2002 (INE 1982; INE 2002). The people who have been migrating are the main workforce, commonly those aged between 15 and 44 (González et al. 1991). This results in resident manpower dominated by the elderly. Also the potential loss of Aymara's traditional practices and local crops variety could lead to a significant loss of cultural heritage and ancestral knowledge.

In Tarapacá, rural human depopulation has also caused deficient care or abandonment of livestock, especially donkeys and Ilamas (Lama glama Linnaeus). This has generated ecological problems and more conflicts. Feral donkeys are now part of the assembly of large herbivores in a desert ecosystem (therefore of limited water and pasture resources) (Fuentes-Allende et al. 2016; Malo et al. 2016), and are also foraging in crops.

The use of dogs as a method against crop raiding could become a major threat to tarukas conservation (Barrio et al. 2017). Fencing represent a direct threat to tarukas as well, as they can get entangled in the wires (CONAF 2006b). Therefore, the construction of peripheral fences around entire villages is not appropriated because increases habitat fragmentation and reduces access to resources such as water (Durant et al. 2015; Fuentes-Allende et al. 2016). Fencing crop plots alone would lessen those effects and is also cheaper.

According to Carrasco et al. (1992) when tarukas are disturbed, they do not return to a place for at least three weeks. Therefore, the construction of fences could have caused the decrease in night encounters because of the presence of workers during their installation. In contrast, Rechberger et al. (2014) stated that their consecutive day's sampling did not affect taruka presence. However, the same study shows how tarukas moved away from an area intensively used by humans and then returned when it was less visited.

Another threat is livestock breeding. Most peasants of the study area have livestock, which could displace tarukas from their habitat, as it occurs elsewhere (Barrio 2004). In the study area domestic herds feed on forage crops and wild vegetation, thus they might be competing with tarukas for the scarce food resources. Also, the substantial increase in goats is worrisome because they are more destructive for plants and soil than domestic camelids, and they exhibit a 
more selective diet (Fowler 2010). Furthermore, spreading of diseases from livestock to wildlife has not been evaluated in northern Chile, which has been documented for huemul deer in Southern Chile (Povilitis 1998). Recently, the first report of tarukas as intermediate hosts of tapeworms (Taenia hydategina) in Peru was published, where domestic dogs, mainly sheepdogs, and Andean fox (Lycalopex culpaeus Molina) are considered definitive hosts (Gomez-Puerta et al. 2015). Therefore, livestock and domestic animals (feral dogs and sheepdogs) could be involved in life cycles of diseases that affect the species.

The distribution of tarukas in Chile is restricted, and their presence is scarcely represented in protected areas (Mata et al. 2019). Their current known presence is mainly linked to agricultural sites (Fuentes-Allende 2017; Mata et al. 2019). Therefore, an effective conservation strategy for the species should consider conflicts with agriculture and its implications.

Our results refute the hypothesis that grazing pressure on crops occurs mainly in the dry season. This implies that, for tarukas, crops are complementary to natural (i.e. not cultivated) food resources in all seasons, independently of the availability and quality of wild vegetation. This pattern was also confirmed by respondents from the Parinacota Province, who stated that they have to deal with tarukas constantly.

If this conflictive interaction is effectively longstanding, crops might be included in the diet of tarukas for a long time. Therefore crops disappearance could imply the removal of an important food source for the currently vulnerable population of tarukas in this xeric habitat, at least for the portion of the population that inhabits near croplands and use to eat crops. Usually discussions about the relationship between agriculture and biodiversity are related to impact of intensive practices and major landscape change (Norris 2008), and rural-urban migration has been considered a promoter of natural ecosystem recovery (Grau \& Aide 2007); but little is known about the potential positive effect of traditional agricultural practices on endangered species like tarukas.

Tarukas natural group composition previously reported for the species were seen in the study area (Sielfeld \& Guzman 2011). Our results agrees with Sielfeld \& Guzman (2011) whom stated that males tended to be more solitary than females; after family groups, solitary males was the second category most recorded. Fawns were always sighted with adult females, as was observed by Merkt (1987). Generally, one taruka in the group, also commonly a female, tends to be more alert than the rest as it has been previously reported for the species (Barrio 2010).

The altitude range here reported for the species (between 3,281 and 3,840 masl) is expected in the southern area of the distribution range (i.e. Chile and Argentina), where tarukas are found at lower altitude than in the northern part of the range, where they can be found above 5,000 masl (Barrio 2010). An isolated record of the species in the northern limit of Chile at 4,671 masl (the highest reported in Chile), is coincident with the described increasing altitudinal range to the northern part of its distribution (Lagos et al. 2017).

Our study contributes to the knowledge and understanding of the conflict. The conflict must be considered to design an effective mitigation and conservation strategy for the species (Woodroffe et al. 2005; Shaffer et al. 2019). We believe that developing strategies that provide sustainable economic viability to peasants, could help to avoid the loss of traditional Aymara agriculture and to improve their relationship with tarukas, which in turn could help tarukas conservation.

\section{ACKNOWLEDGEMENTS}

We are grateful to Hernán Rojas, José Tomás Ibarra, Cristián Yurisic, Daniela Sierralta, Jerry Laker, Paulina Andreu and Oscar Skewes for their support in field work. Staff from CONAF (National Forestry Corporation) and SAG (National Agriculture and Livestock Service) of Putre, and the frontier Police also provided logistic support. A special thanks to Niall McCann for comments of early drafts of this manuscript. We thank Jorge Herreros and Monica Piña for receiving us in Arica. This work was funded by Wildlife Trust, The Macs Project (Manejo Sostenible de Camélidos Sudamericanos Silvestres - ICA4-2000-10299), and the Interdisciplinary Center for Intercultural and Indigenous Studies - CIIR, GRANT: CONICYT/FONDAP/15110006.

\section{REFERENCES}

Barrio, J. 2004. Possible cattle influence on the population of two deer species at the highlands of Río Abiseo National Park, Perú. IUCN (International Union for Conservation of Nature) Deer Specialist Group News IUCN 19: 6-9.

Barrio, J. 2010. Taruka, Hippocamelus antisensis (D'Orbigny, 1834). pp. 77-88. In: Duarte, J.M.B., González, S. (eds). Neotropical Cervidology, biology and medicine of Latin American deer. FUNEP (Fundação de Apoio a Pesquisa, Ensino e Extensão) and IUCN (International Union for Conservation of Nature), Jaboticabal, Brasil and Gland, Suiza.

Barrio, J., Nuñez, A., Pacheco, L., Regidor, H.A. Fuentes-Allende, N. 2017. Hippocamelus antisensis. The IUCN Red List of Threatened Species 2017: e.T10053A22158621. https://dx.doi.org/10.2305/IUCN.UK.2017-2.RLTS. 
T10053A22158621.en (Accessed: May 18, 2020).

Bonacic, C., Muñoz, A.E. 2006. El guanaco (Lama guanicoe) y taruca (Hippocamelus antisensis) en precordillera, presencia y uso del hábitat. pp. 13-17. In: Bonacic, C., Muñoz, A.E. (eds). Experiencias de relación entre vida silvestre y comunidades Aymaras de la Provincia de Parinacota: estudios de caso. Laboratorio de Investigación Fauna Australis, Pontificia Universidad Católica de Chile y Secretaría Regional Ministerial de Agricultura, I Región de Tarapacá, Arica, Chile.

Bonacic, C., Ibarra, J.T. 2010. Fauna Andina: historia natural y conservación. Serie Fauna Australis. Facultad de Agronomía e Ingeniería Forestal, Pontificia Universidad Católica de Chile. División Andina, Codelco Chile.

Borgnia, M., Vilá, B.L., Cassini, M.H. 2008. Interaction between wild camelids and livestock in an Andean semi-desert. Journal of Arid Environments 72: 2150-2158.

Caqueo-Urízar, A., Urzúa, A., De Munter, K. 2014. Mental health in indigenous school children in Northern Chile. BMC Psychiatry 14: 11.

Carevic, A. 2008. Degradación o sustentabilidad de los campesinos en el desierto chileno. Industrias Gráficas Tarapacá. Iquique, Chile. 307 pp.

Carrasco, C., Sielfeld, W., González, E. Torres, J. 1992. La Taruca (Hippocamelus antisensis) y la interacción con el hombre en la I región de Chile. pp. 49-61. In: Ortiz, C. (ed). Seminario internacional: Cérvidos nativos e introducidos en Chile.

Comuna de Putre. 2012. Plan Anual de Desarrollo Educativo Municipal "PADEM". Departamento de Administración Educacional de la llustre Municipalidad de Putre y Establecimientos Educativos, Chile.

CONAF. 2006a. Informe de Evaluación de Cercos. In: Diagnóstico Poblacional del Guanaco y Taruca en la provincia de Parinacota. Corporación Nacional Forestal, Arica, Chile.

CONAF. 2006b. Informe de Evaluación: Construcción del cierre perimetral en la localidad de Socoroma. In: Diagnóstico Poblacional del Guanaco y Taruca en la provincia de Parinacota. Corporación Nacional Forestal, Arica, Chile.

Det Kongelige Bibliotek. 2001. GKS $22324^{\circ}$ : Guaman Poma, Nueva crónica y buen gobierno (1615). Department of Manuscripts and Rare Books, Copenhague, Denmark. URL: http://www.kb.dk/permalink/2006/poma/1145/ es/text/ (Accessed: May 18, 2020).

Distefano, E. 2005. Human-wildlife conflict worldwide: a collection of case studies, analysis of management strategies and good practices. FAO (Food and Agriculture Organization) and SARD. Rome, Italy.

Durant, S.M., Becker, M.S., Creel, S., Bashir, S., Dickman, A.J., Beudels-Jamar, R.C., Lichtenfeld, L., Hilborn, R., Wall, J., Wittemyer, G., Badamjav, L., Blake, S., Boitani, L.,
Breitenmoser, C., Broekhuis, F., Christianson, D., Cozzi, G., Davenport, T.R.B., Deutsch, J., Devillers, P., Dollar, L., Dolrenry, S., Douglas-Hamilton, I., Dröge, E., Fitzherbert, E., Foley, C., Hazzah, L., Hopcraft, J.G.C., Ikanda, D., Jacobson, A., Joubert, D., Kelly, M.J., Milanzi, J., Mitchell, N., M'soka, J., Msuha, M., Mweetwa, T., Nyahongo, J., Rosenblatt, E., Schuette, P., Sillero-Zubiri, C., Sinclair, A.R.E., Stanley Price, M.R., Zimmermann, A., Pettorelli, N. 2015. Developing fencing policies for dryland ecosystems. Journal of Applied Ecology 52: 544-551. https://doi. org/10.1111/1365-2664.12415

Fowler, M.E. 2010. Medicine and surgery of South American Camelids. John Wiley and Sons. Ames, lowa.

Fuentes-Allende, N., Vielma, A., Paulsen, K., Arredondo, C., Corti, P., Estades, C.F., González, B.A. 2016. Is human disturbance causing differential preference of agricultural landscapes by taruka and feral donkeys in high Andean deserts during the dry season? Journal of Arid Environments 135: 115119. https://doi.org/10.1016/j.jaridenv.2016.08.018

Gomez-Puerta, L.A., Pacheco, J., Gonzales-Viera, O., LopezUrbina, M.T., Gonzalez, A.E. 2015. The taruca (Hippocamelus antisensis) and the red brocket deer (Mazama americana) as intermediate hosts of Taenia hydatigena in Peru, morphological and molecular evidence. Veterinary Parasitology. 212: 465-468. https:// doi.org/10.1016/j.vetpar.2015.08.004

González, H., Gundermann, H., Rojas, R. 1991. Diagnóstico y Estrategia del Desarrollo Campesino en la I región de Tarapacá, Chile. Taller de Estudios Andinos (TEA), Arica, Chile.

Gordon, I. 2009. What is the future for wild, large herbivores in human-modified agricultural landscapes? Wildlife Biology 15: 1-9.

Grau, R., Aide, M. 2007. Are rural-urban migration and sustainable development compatible in mountain systems? Mountain Research and Development 27(2): 119-123.

INE. 1982. Censos 1970-1982, cifras comparativas. Instituto Nacional de Estadísticas, Santiago, Chile.

INE. 1997. VI Censo Nacional Agropecuario 1997, Resultados Preliminares. Instituto Nacional de Estadísticas, Santiago, Chile.

INE. 2002. Censo 2002, Resultados. Volumen I: Población País Región. Instituto Nacional de Estadísticas, Santiago, Chile. URL: http://www.memoriachilena.gob.cl/archivos2/pdfs/ MC0055471.pdf (Accessed: May 14, 2020).

INE. 2007. VII Censo Nacional Agropecuario y Forestal 2007. Instituto Nacional de Estadísticas, Santiago, Chile. URL: http://webanterior.ine.cl/estadisticas/economicas/ estad\%C3\%ADsticas-agropecuarias (Accessed: May 18, 2020). 
Jiménez, J.E. 1994. Overuse and endangerment of wildlife: the case of Chilean mammals. Medio Ambiente 12: 102-110.

Lagos, N., Fuentes-Allende, Nicolás Sepúlveda, N., Gamboa, F., Hernández, J., González, B.A. 2017. New record for taruka (Hippocamelus antisensis) in the Chilean Puna after 40 years. Are we looking for the deer in the right places? Deer Specialist Group Newsletter IUCN: 16-22.

Luebert, F., Pliscoff, P. 2006. Sinopsis bioclimática y vegetacional de Chile. Editorial Universitaria, Santiago, Chile. 316 pp.

Malo, J.E., González, B.A., Mata, C., Vielma, A., Donoso, D.S., Fuentes, N., Estades, C.F. 2016. Low habitat overlap at landscape scale between wild camelids and feral donkeys in the Chilean desert. Acta Oecologica 70: 1-9. https:// doi.org/10.1016/j.actao.2015.11.002

Mata, C., Fuentes-Allende, N., Malo, J.E., Vielma, A., González, B.A. 2019. The mismatch between location of protected areas and suitable habitat for the vulnerable taruka Hippocamelus antisensis. Oryx 53: 752-756. https://doi. org/10.1017/S0030605317001740

Merkt, J.R. 1987. Reproductive seasonality and grouping patterns of the North Andean deer or Taruca (Hippocamelus antisensis) in Southern Perú. pp. 388-401. In: Wemmer, C. (ed). Biology and management of the Cervidae. Washington, DC, USA.

MINSEGPRES. 2007. Decreto Supremo 151/2006. Oficializa Primera Clasificación de Especies Silvestres Según su Estado de Conservación. Ministerio Secretaría General de la Presidencia, Gobierno De Chile, Santiago, Chile.

Muñoz, A.E., Bonacic,C. 2006. Variación estacional de la flora y vegetación en la precordillera andina de la comuna de Putre (I Región de Tarapacá, Chile) durante el período 2002-2003. Gayana Botanica 63(1): 75-92.

Norris, K. 2008. Agriculture and biodiversity conservation: opportunity knocks. Conservation Letters 1: 2-11.
Povilitis, A. 1998. Characteristics and conservation of a fragmented population of huemul Hippocamelus bisulcus in central Chile. Biological Conservation 86: 97-104.

Rechberger, J., Pacheco, L.F., Nuñez, A., Roldán, A.I., Martínez, O., Mendieta, G. 2014. The recovery of a population of the Vulnerable taruka Hippocamelus antisensis near La Paz, Bolivia: Opportunities for conservation and education. Oryx 48: 445-450. https://doi.org/10.1017/ S0030605312001561

Shaffer, L.J., Khadka, K.K., Van Den Hoek, J., Naithani, K.J. 2019. Human-Elephant Conflict: A Review of Current Management Strategies and Future Directions. Frontiers in Ecology and Evolution 6: 1-12.

Sielfeld, W., Carrasco, C., González, G., Torres, J. 1999. La taruca (Hippocamelus antisensis D'Orbigny, 1834) en la Provincia de Parinacota, Región de Tarapacá, Chile: población, hábitat y alimentación. Anales del Museo de Historia Natural de Valparaíso 24: 95-108.

Sielfeld, W., Guzmán, J.A. 2011. Distribution, reproduction and grouping patterns in the taruca deer (Hippocamelus antisensis D'Orbigny, 1834) in the extreme north of Chile. Animal Production Science 51: 180-190.

Skewes, O. 2009. Manual de huellas: mamíferos silvestres de Chile (nativos y exóticos). Universidad de Concepción, Facultad de Ciencias Veterinarias, Chillán.

Weber, M., González, S. 2003. Latin American deer diversity and conservation: a review of status and distribution. Ecoscience 10: 443-454.

Wheeler Pires-Ferreira, J., Pires-Ferreria, E., Kaulicke, P. 1976. Preceramic animal utilization in the Central Peruvian Andes. Science 194: 483-490.

Woodroffe, R., Thirgood, S., Rabinowitz, A. (eds). 2005. People and Wildlife, Conflict or Co-existence? Cambridge University Press, Cambridge, UK. 516 pp.

Received: 26.06 .2020

Accepted: 29.03.2021 
APPENIDX 1. Questionnaire applied to farmers. / Cuestionario aplicado a los agricultores.

\section{Questions related to farming practices}

1) How much area of land do you cultivate?

2) What crops do you produce?

3) Apart from farming, are you engaged in other activity? Which one?

4) (In the case of livestock keepers) What kind of livestock do you have?

5) How many individuals by type of livestock?

\section{Questions related to farmer-taruka conflict}

1) Have you detected occurrence of crop raiding by wild ungulates in your crops? Which one?

2) When? Continuously or in some particular season?

3) Do you use any protection methods against tarukas foraging in your crops? Which method?

APPENDIX 2. Review of methods of protection and plant damaged by wildlife in crop fields in the study area. / Revisión de métodos de protección y daño a cultivos por vida silvestre en el área de estudio.

\begin{tabular}{|c|c|c|c|c|}
\hline Crop & Sector & Protection method & Damaged plants (\%) & Cause \\
\hline alfalfa & Chapiquiña & scarecrow & 11 & grazing and trampling \\
\hline alfalfa & Chapiquiña & scarecrow & 5 & grazing and trampling \\
\hline alfalfa & Murmuntani & scarecrow & 55 & grazing and trampling \\
\hline alfalfa & Murmuntani & broken fence & 95 & grazing and trampling \\
\hline pea & Belén & scarecrow & 10 & trampling \\
\hline pea & Murmuntani & insecticide and scarecrow & 20 & grazing and trampling \\
\hline corn & Chapiquiña & none & 4 & grazing and trampling \\
\hline corn & Chapiquiña & none & 0 & \\
\hline corn & Chapiquiña & scarecrow & 0 & \\
\hline corn & Belén & scarecrow & 0 & \\
\hline corn & Belén & fence and scarecrow & 0 & \\
\hline corn & Murmuntani & insecticide and scarecrow & 0 & \\
\hline broad bean & Chapiquiña & none & 0 & \\
\hline broad bean & Belén & scarecrow & 0 & \\
\hline broad bean & Belén & fence and scarecrow & 0 & \\
\hline broad bean & Murmuntani & insectide and scarecrow & 5 & grazing and trampling \\
\hline broad bean & Murmuntani & scarecrow & 0 & \\
\hline oregano & Chapiquiña & none & 0 & \\
\hline oregano & Belén & scarecrow & 0 & \\
\hline oregano & Murmuntani & none & 0 & \\
\hline
\end{tabular}

